\begin{tabular}{|c|c|}
\hline 7 & $\begin{array}{c}\text { International Journal of Current Research } \\
\text { and Academic Review }\end{array}$ \\
\hline${ }_{\mathrm{NT}}^{\mathrm{NT}}$ & $\begin{array}{c}\text { ISSN: 2347-3215 (Online) } \because, \text { Volume } 5 \\
\text { Journal homepage: http://www.ijcrar.com } 7 \text { (July-2017) }\end{array}$ \\
\hline
\end{tabular}

doi: https://doi.org/10.20546/ijcrar.2017.507.014

\title{
Process of Colonization by Necrophagous Insects, of a Pig Corpse (Sus scrofa domesticus L.) Exposed at Open Air, in the Southern Forest Zone of Côte d'ivoire
}

\author{
Koffi Alexandre Franklin ${ }^{1,3^{*}}$, Aboua Louis Roi Nondenot ${ }^{1}$, Dao Hassane ${ }^{1}$, Djojo Mathurin ${ }^{2}$, \\ D.E. Koffi-Tebele Joëlle ${ }^{3}$, E.Y. Kpama-Yapo Carine ${ }^{1}$
}

${ }^{I}$ Félix Houphouët Boigny University of Cocody-Abidjan-Côte d'Ivoire, UFR Biosciences, Laboratory of Zoology and Animal Biology, 22PO BOX 582 Abidjan 22

${ }^{2}$ UFR Medical Sciences, Forensic Medicine Institut of Abidjan-Côte d'Ivoire

${ }^{3}$ National Institute of Public Hygiene, Abidjan-Côte d'Ivoire PO BOX V 14 Abidjan

*Corresponding author

\begin{abstract}
The aim of this work was to demonstrate the existence of a diverse necrophagous entomological fauna and the order in which these insects appear to colonize a decaying corpse in the open air in the southern forest zone of Côte d'Ivoire. At the three sites selected in the city of Abidjan, Calliphoridae Diptera (1058 \pm 129.73 individuals trapped), Sarcophagidae $(317.33 \pm 14.38)$ and Muscidae $(152.33 \pm 11.46)$, occurring between the 1 st and 14th post mortem days, were the first group of insects that colonized the exposed pig carcasses. Between the 14th and the 28th day post mortem, a second group mainly composed of Piophilidae Diptera $(767 \pm 87.30$ individuals harvested) and Coleoptera belonging to the Cleridae $(803.33 \pm 73.64)$ and Histeridae families $(15.67 \pm 1.85)$, appeared. The family of Stratiomyidae (339.67 \pm 49.76 individuals trapped) occurred between the 35 th and 42nd post mortem days. These formed with the Piophilidae and the Cleridae, the third group that stayed until the 91st day post mortem. During the advanced decomposition phase, the Coleoptera Dermestidae, Tenebrionidae and Trogiidae appeared. They were added to the necrophagous insects of the third group to constitute the fourth group.The identification of the necrophagous Diptera trapped, made it possible to note the preponderance of the genera Piophila spp. and Chrysomya spp. They represented for $29.12 \%$ and $26.57 \%$ respectively of the total number of Diptera trapped. The least represented genera were Musca spp. and Calliphora spp. with $5.78 \%$ and $3.45 \%$ of the total number of Diptera harvested. For Coleoptera, the Cleridae family was the most represented with $91.01 \%$ of the total number of individuals harvested at the three sites.As part of an entomological assessment to date a death, these first results give an overview of the entomological fauna existing in the Guinean zone of Côte d'Ivoire and the way it gradually colonizes, a corpse exposed to the outdoors.
\end{abstract}

\section{Article Info}

Accepted: 22 June 2017

Available Online: 20 July 2017

\section{Keywords}

Necrophagous insects, Squads, Calliphoridae, Southern forest zone, Open air.

\section{Introduction}

During the process of decomposition of a corpse accessible to the necrophagous fauna, various groups of insects follow one another to colonize it (Mégnin, 1894).
This notion of squads was taken up by Leclercq (1978), and by (Wyss and Cherix 2006). These authors reported that Mégnin's first squads did not correspond to those they observed. These squads could not provide reliable guidance in the establishment of the Post Mortem 
Interval (PMI). Nevertheless, they remain practical to locate species in the process of colonization. The number and variety of necrophagous insects differ depending on whether the corpse is exposed to the open air, or immersed, or buried (Amendt et al., 2000, Campobasso et al., 2001). Regardless of the conditions under which a corpse is found (in the open air, buried, submerged, etc.), the composition of the squads and their "working time" may vary depending on the factors that influence the local entomological fauna and processes of alteration of the corpse; these include: the region and its geographic area, the type of locality (city or countryside), the type of location (inside or outside), climate and weather (including season), storage of bodies and the volume of the corpse (Campobasso et al., 2001).In Côte d'Ivoire, there is very little literature on necrophagous insects, particularly those of Adou (2014) on forensic anthropology and those of Dao et al. (2017) and Yapo et al. (2017) on respectively the biology of Sarcophaga carnaria(Diptera: Sarcophagidae) and Lucilia sericata(Diptera: Calliphoridae)The aim of this study, which is part of the establishment of the repertory of necrophagous insects in Côte d'Ivoire, is to identify the different groups of insects involved in the decomposition process of a corpse exposed in the southern forest zone of Côte d'Ivoire, particularly in the city of Abidjan.

\section{Materials and Methods}

\section{Study site}

This study was carried out in the Guinean zone (southern forest region) of Côte d'Ivoire, specifically in the city of Abidjan ( $\left.5^{\circ} 20^{\prime} 11^{\prime \prime} \mathrm{N}-4^{\circ} 1{ }^{\prime} 36^{\prime \prime} \mathrm{W}\right)$. The experimental sites chosen and constituting three replicates are the National Center for Agronomic Research (NCAR/CNRA, Adiopodoumé Km 17, / 5¹9'40.13"N - 407'54.80"W Altitude $17 \mathrm{~m})$, National Zoo of Abidjan ( $5^{\circ} 22^{\prime} 48.90^{\prime \prime} \mathrm{N}$ $4^{\circ} 00^{\prime} 18.41^{\prime \prime} \mathrm{W}$ - Altitude $57 \mathrm{~m}$ ) and the National Center of Floristic (NCF/CNF- 5'20'50.41"N - 3 ${ }^{\circ} 59^{\prime} 01.92 " \mathrm{~W}$ Altitude 49m) from Félix Houphouët-Boigny University of Cocody. As the crow flies, the distance between the CNRA site and that of the National Zoo of Abidjan is $15.26 \mathrm{~km}$. The distance between the National Zoo of Abidjan and the CNF is $4.52 \mathrm{~km}$. That between CNRA and $\mathrm{CNF}$ is $16.53 \mathrm{~km}$. These three sites each have the characteristics of the sub-equatorial climate, warm and humid (Figure 1).

\section{Experimental equipment}

The experimental apparatus was installed on each site, in an open air. For each site, it includes two metal grids.
The first grid G1 was inspired of the Upton trap (Upton, 1991). It is made of fine meshes of $1 \mathrm{~mm}$ diameter. Cones (base $15 \mathrm{~cm}$ diameter / apex $1.5 \mathrm{~cm}$ diameter) are placed on the walls to facilitate the entrance of the Diptera. The latter are then trapped in a reservoir bucket placed above the grid (Figure 2A). As for the second grid G2, it gives access to all necrophagous insects of all sizes by means of a large-mesh metal grid approximately $3.5 \mathrm{~cm}$ to $4 \mathrm{~cm}$ diameter (Figure 2B). The two grids are spaced of $300 \mathrm{~m}$ apart. On each site, a "IHM - 0172SI" thermohygrometer recorder was installed to record daily atmospheric temperatures and relative humidity. Rainfall data were provided by the Meteorological Service of SODEXAM -Abidjan (Société d'Exploitation et de Developpement Aeroportuaire, Aeronautique et Meteorologique).The choice of domestic pigs as biological material is explained by the fact that it is considered an excellent model for the decomposition of the human corpse (Anderson and Van Laerhoven, 1996, Rodriguez and Bass, 1983, Catts and Goff, 1992). There were six (06) pig corpses in the study, two (02) per site and one (01) per grid.

\section{Methods}

\section{Slaughter and exhibition of pig carcasses}

Pigs were obtained from a standard commercial breeding and weighed an average of $60 \mathrm{~kg}$ each. Alive and in perfect health, they were examined and then calmed with a tranquilizer administered by a veterinary surgeon. They were then euthanized. This slaughter was carried out the same day in the morning some few minutes apart, the time to move from one experimental site to another. This day of slaughter on 17 March 2016 is marked $D_{0}$. At each site, the pigs were exposed to necrophagous insects just after slaughter.

\section{Harvesting and identification of insects associated with cadavers}

The necrophagous insects involved in the decomposition process, from the early hours to the skeletal stage of the corpse, were directly harvested from the pig's carcasses.In order to identify insects associated with cadavers, eggs laid on the carcass by some species were harvested and incubated on a substrate in the laboratory for hatching. The larvae that hatched from it were followed until imaginal emergence. For other species, adults were obtained from larvae or nymphs taken away on or near the decaying corpse. For others, adults were directly harvested inside the decaying corpse, using soft 
pliers. Some of the larvae, nymphs and insect adults harvested were stored in labeled pills containing alcohol $60^{\circ}$. Identification of the insects was done using a "Optika LAB20" binocular lens and various identification keys (Prins, 1982, Smith, 1986, Delvare and Alberlenc, 1989, Regina 2002, Wyss and Chérix, 2006, Couri, 2007, Claudio and Cátia, 2008, Szpila, 2009, Whitworth, 2010, Irish, 2014, Rochefort et al., 2015). Most of the insects harvested have been identified up to the taxonomic level of order, family and genus.

For the quantification of necrophagous species, several techniques adapted to the type of insects harvested were used. In the case of large adult Diptera, such as Calliphoridae, Sarcophagidae, Muscidae and Stratiomyidae attracted by carcass, a reservoir bucket was placed above the G1 grid to trap them. This device is inspired by that of Upton (1991) and allowed to trap the Dipterans present on the carcass thanks to a cone which facilitates the access to the bucket reservoir and which prevents them from coming out.

For catching small Diptera such as Piophilidae and other flying insects, a netting was used at the gridG2. Catches were taken three times a day (morning at $7 \mathrm{am}$, noon and $6 \mathrm{pm}$ ) during the first seven post-mortem days and once daily from the seventh day until total skeletonization. In order to diversify catches at the level of beetles, a harvest was carried out using soft claws and four "pittfall traps" were placed around the corpses of the gridsG2: one on the ventral side, one on the dorsal side, one at the level of the head and one at the level of the anus. These are glass jars, $15 \mathrm{~cm}$ high and $8 \mathrm{~cm}$ diameter, filled with a third of soapy water. These are exposed to the surface of the soil and placed at an average distance of $15 \mathrm{~cm}$ from the carcass. The contents of the buckets and glass jars were emptied weekly. The insects harvested were stored in labeled pills containing alcohol at $60^{\circ}$. They were then separated and grouped by order, family and genus to be counted. The post-mortem follow-up period extended from march 17, 2016 to june 30, 2016, whether 105 days (Figure 2).

\section{Follow-up of the process of insect colonization and decomposition of cadavers}

Post-mortem follow-up was extended from March 17, 2016 to June 30, 2016. During this period, details of the various changes in the cadavers were recorded daily. The different stages of decomposition have been described as well as the order of appearance of necrophagous insects.

\section{Data processing}

The insects collected at the three sites were counted. Second, the average number was calculated. The software Statistica version 7.1 was used to perform ANOVA variance analyzes. The Newman-Keuls test, at the $5 \%$ probability threshold, allowed to separate the different homogeneous groups.

\section{Results and Discussion}

The identification of adult insects harvested by trapping and/or after breeding allowed them to be distributed within 5 orders: Diptera, Coleoptera, Hymenoptera, Orthoptera and Dictyoptera. Among these, only Diptera and Coleoptera are effectively necrophagous. The Hymenoptera, mainly represented by the Formicidae family, were predators feeding the larvae of necrophagous Diptera. Orthoptera and Dictyoptera were classified as omnivores and opportunists, appearing at the time when the carcass was completely dried. As these last three orders were not used in the estimation of the post-mortem period, their representatives were not counted.The total number of adult necrophagous insects harvested during this experiment at all three sites amounts to 10551 individuals. The Diptera order alone had 7903 individuals, whether $74.9 \%$ of the total number. The Coleoptera had 2648 individuals, whether $25.1 \%$ of the total number.

\section{Order of Diptera}

The adult necrophagous Diptera collected at the three sites belonging tofive families: Calliphoridae, Sarcophagidae, Muscidae, Piophilidae and Stratiomyidae. The total number of adult necrophagous Diptera trapped was 7903 individuals. Specimens belonging to the Calliphoridae family were the most numerous with an average of $1058 \pm 129.73$ individuals trapped per site. Then come those of the Piophilidae family with an average of $767 \pm 87.30$ individuals harvested per site. Finally, the stratiomyidae, Sarcophagidae and Muscidae families had respectively an average of $339.67 \pm 49.76,317.33 \pm 14.38$ and 152.33 \pm 11.46 individuals trapped per site (Table 1 ).

The identification of individuals up to the taxonomic level of the genus made it possible to note in the Diptera necrophagous trapped, the preponderance of the genera Piophila spp. and Chrysomya spp. The analysis of the numbers obtained shows that the genera Piophila spp. and Chrysomya spp. accounted for $29.12 \%$ and $26.57 \%$ 
of the total number of Diptera trapped. The least represented genera were Musca spp.and Calliphora spp. with respectively $5.78 \%$ and $3.45 \%$ of the total number of Diptera harvested. The families of Sarcophagidae and Stratiomyidae were mainly represented by the genera Sarcophaga spp. (12.05\%) and Hermetia spp. (12.89\%) (Figure 3).

\section{Order of Coleoptera}

The beetles harvested in this study were distributed within six (06) families: Cleridae, Histeridae, Dermestidae, Tenebrionidae, Trogiidae and Scarabeidae. The total number of individuals trapped in all three sites was 2648 specimens, whether $25.1 \%$ of the total number of all necrophagous insects trapped in the experiment. At the CNRA, National Zoo of Abidjan and CNF sites, the Cleridae family showed the greatest number of trapped individuals, with respectively 891, 657 and 862 specimens, an average of $803.33 \pm 73.64$ individuals harvested by site. The Cleridae averaged $91.01 \%$ of the total number of beetles harvested at the three sites. The family of Dermestidae was in second position with an average of $29.33 \pm 12.11$ individuals harvested per site. The families of Tenebrionidae, Histeridae and Trogiidae followed respectively with an average of $18.33 \pm 2.02$, $15.67 \pm 1.85$ and $14.33 \pm 2.02$ individuals trapped per site. The Scarabeidae family was the least represented with an average of $1.67 \pm 0.88$ individuals harvested per site (Table 2).

\section{Process of colonization of pig carcasses by necrophagous insects}

The experiments carried out on the three sites showed an order of appearance and colonization by necrophagous insects of exposed pig carcasses. This process took place under ambient conditions. The decomposition of the corpses took place in 4 phases on the three sites: $d_{0}=$ fresh corpse, $d_{1}$ to $d_{7}=$ swelling followed by active decomposition, $\mathrm{d}_{7}$ to $\mathrm{d}_{84}=$ advanced decomposition, $\mathrm{d}_{91}$ to $\mathrm{d}_{105}=$ skeletonisation (Table 3$)$.

At the three experimental sites, the Calliphoridae, Sarcophagidae and Muscidae Diptera were the first group of insects that colonized exposed pig carcasses. Then, between the 14th and 28th post mortem days, a second group, mainly composed of Piophilidae Diptera, Cleridae Coleoptera and Histeridae Coleoptera, gradually took over. Stratiomyidae Diptera appeared between the 35 th and 42nd post mortem days. These have formed with the Piophilidae and Cleridae, the third group which has been maintained until the 91st day after mortem. During the advanced decomposition phase, the Coleoptera Dermestidae, Tenebrionidae and Trogiidae appeared. They joined the necrophagous insects of the third group to form the 4th group (Figure 4).

The pig carcasses used in these experiments were exposed in open areas to facilitate their colonization by necrophagous insects. A few hours after the killing and exposure of pig carcasses to the open air, many Diptera adults belonging to the Calliphoridae, Sarcophagidae and Muscidae families were attracted by the first smells emitted by the beginning of the decomposition. The early presence of the latter is due to the fact that they have a highly developed olfactory device, enabling them to detect very low odors emitted by corpses. The presence of all the insects harvested during this period of decomposition is due to the characteristic odor emitted by the corpses and to the presence of chemical sensors on the antennas of the insects. This argument is consistent with that of Picimbon (2002), who reported that molecular or family-specific sensitizes function as peripheral microsensors of the fragrant molecules of the environment. This early colonization of corpses by these families was also observed by Lee (1989), Lee et al. (2004), Dekeirsschieter (2007) and (Silahuddin et al., 2015). Numerous clusters of eggs were laid by these families. These eggs were essentially laid at various places on the hidden side (in contact with the ground) of the corpse. They were also laid at the level of the eyes, the anus and the orifices of the snout and the mouth. The choice of these places by these Diptera, at the level of the corpse, to lay, could be explained by the fact that they want to protect their eggs, against the luminous intensity and the heat of the sun. This phenomenon was also observed by Wyss (2000), during his work on Pig97 and Pig99, during which he described the behavior of heliophobia. Eggs and first instar larvae taken from the cadavers on the first day (PMI $=\mathrm{D}_{1}$ ) day after exposure, recorded the emergence in the laboratory of Diptera adult belonging to the Calliphoridae, Sarcophagidae and Muscidae families. They constitute the first group of necrophagous insects that colonized the corpses exposed in the southern forest zone of Côte d'Ivoire from the first hours after death. Early colonization of a corpse exposed to the open air by these Diptera was also reported by Leclercq (1996), in a study of entomological fauna, progressively colonizing a wild boar, which died accidentally in the forest of the National Domain of Chambord, in France. Our results are consistent with those of Wyss (2000), Wyss and Cherix (2006), Dekeirsschieter (2007), Goff (2009) and (Carmo and 
Vasconcelos, 2016). As part of an entomological assessment to date the deaths in Côte d'Ivoire, the families of this first group of insects could be used to establish a short post-mortem interval. From $D_{1}$ to $D_{7}$ post mortem, the corpses were totally invaded by larvae in instar 1, instar 2 and instar 3 of this first group of Diptera. The corpses were then in active decomposition phase. Seven (7) days after exposure, many third instar larvae began to move away from the decaying carcass to initiate the post-feeding instar occurring just before pupation. These observations are consistent with those of Yapo et al. (2017) who studied some aspects of the biology of Lucilia sericata, whose larvae were raised on pig and beef liver. Between the 7th and 14th postmortem days, the number of larvae and adults belonging to the first group (Calliphoridae-SarcophagidaeMuscidae)decreased sharply. This phenomenon could be explained by the state of the corpse. Indeed, at this stage and in the absence of rain, the corpse whose skin has completely dried, no longer favors the egg laying of the females of this first group. Between the 14th and the 28th day post mortem, the juvenile and adult stages of the first group have disappeared from the corpse ecosystem. Within this time interval, began to appear some adults of Piophilidae Diptera, Coleoptera Cleridae and Coleoptera Histeridae. They formed the second group that appeared at the level of the corpse. Their presence would be due to the body's internal moisture and fat rancidity (Watson and Carlton, 2005). Between the 35th and 42nd post mortem days, juvenile and adult stages of Stratiomyidae Diptera appeared. At this stage, they formed with larvae and adults of Piophilidae and Cleridae, Histeridae and Dermestidae, a third group. The number of juvenile and adult stages of this group increased exponentially between the 49th and 84th post mortem days. The late appearance of Stratiomyidae may be explained by the fact that their larvae can only develop on corpses in advanced decomposition.

Indeed, according to the work of Lord et al. (1994) and those of Turchetto (2000), Stratiomyidae would be attracted by characteristic odors emitted by the corpse in advanced decomposition phase. When the corpse was completely dried, between the 56th and 63rd post mortem days, adults of Tenebrionidae, Trogiidae and Staphilinidae Coleoptera appeared in very small numbers. They constituted the fourth group and could be with the Dermestidae, predators of larvae and nymphs of Piophilidae and Stratiomyidae Diptera. These observations are similar to those of Feugang et al. (2011), who studied in Cameroon the composition of entomological necrophagous fauna, using rat cadavers.
However, their reduced number could be explained by the fact that the experimental sites are located in highly anthropized urban environments (Gillon, 1990). The order of appearance and colonization of pig corpse exposed, by the necrophagous insects observed during these experiments shows many similarities with the progressive succession of necrophagous insects on a human corpse proposed by Byrd and Castener (2001), based on experiments in eastern Tennessee, USA. Orthoptera and Dictyoptera appeared much later in the corpse, when it was at a very advanced stage of decomposition, close to the skeletal phase. The order of Hymenoptera was essentially represented by ants (Formicidae) predators of Diptera larvae. These have mainly proliferated at the moment when the larvae of Diptera were very abundant within the corpse in active decomposition phase.

\section{Conclusion}

The pig carcasses exposed to the open air and in an open environment, at three sites remote from each other in the city of Abidjan, were colonized by necrophagous insects. The trapping and enumeration of the individuals present in the corpses revealed the preponderance of two large insect orders, namely Diptera and Coleoptera. In addition to the latter, the presence of Hymenoptera, Dictyoptera and Orthoptera was noted.During the active decomposition stage of pigs, which extended from the 1 st to the 14th post-mortem day, the Diptera belonging to the families Calliphoridae, Sarcophagidae and Muscidae were the first group of necrophagous insects to colonize the corpses exposed. As these families tended to disappear at the beginning of advanced decomposition, between the 14th and the 21 st post mortem day, a second group was beginning to form. This second group was constituted of Diptera Piophilidae and Coleoptera belonging to the families of Cleridae, Histeridae and Scarabeidae.

Between the 35th and 42nd post mortem days, the Diptera of the Stratiomyidae family appeared. These were added to the insects of the second group to form the third group constituting of the families of Piophilidae, Cleridae, Histeridae, Dermestidae and Stratiomyidae. During the advanced decomposition phase, between the 77th and 84th post mortem days, the Coleoptera belonging to the Tenebrionidae, Trogiidae and Staphylinidae families appeared. They joined the insects of the third group to form the fourth group. These were harvested in very small numbers at the level of completely dried corpses. 
Table.1 Average number of necrophagous adults Diptera collected at the sites of the CNRA, ZOO and CNF

\begin{tabular}{ccccc}
\hline Families & $\begin{array}{c}\text { Site of } \\
\text { CNRA }\end{array}$ & Site of ZOO & Site of CNF & $\begin{array}{c}\text { Average number per } \\
\text { Site }\end{array}$ \\
\hline Calliphoridae & 972 & 889 & 1313 & $1058.00 \pm 129.73^{\mathbf{a}}$ \\
Sarcophagidae & 301 & 346 & 305 & $317.33 \pm 14.38^{\mathbf{c}}$ \\
Muscidae & 135 & 148 & 174 & $152.33 \pm 11.46^{\mathbf{c}}$ \\
Piophilidae & 939 & 707 & 655 & $767.00 \pm 87.30^{\mathbf{b}}$ \\
Stratiomyidae & 333 & 257 & 429 & $339.67 \pm 49.76^{\mathbf{c}}$ \\
\hline Total number of Diptera per site & 2680 & 2347 & 2876 & - \\
\hline Total number of Diptera in all sites & & & 7903 &
\end{tabular}

ANOVA followed by the Newman-Keuls test at the 5\% threshold, $\mathrm{N}=3 ; \mathrm{P}=0.000031 ; \mathrm{ddl}=4 ; \mathrm{F}=25.63$. The numbers followed by the same letter are not significantly different according to the Newman Keuls test at the $5 \%$ threshold.

Table.2 Average number of necrophagous adult beetles collected at the sites of the CNRA, ZOO and CNF

\begin{tabular}{ccccc}
\hline Families & $\begin{array}{c}\text { Site of } \\
\text { CNRA }\end{array}$ & $\begin{array}{c}\text { Site of } \\
\text { ZOO }\end{array}$ & $\begin{array}{c}\text { Site of } \\
\text { CNF }\end{array}$ & $\begin{array}{c}\text { Average number per } \\
\text { site }\end{array}$ \\
\hline Cleridae & 891 & 657 & 862 & $803.33 \pm 73.64^{\mathbf{a}}$ \\
Histeridae & 18 & 17 & 12 & $15.67 \pm 1.85^{\mathbf{b}}$ \\
Dermestidae & 53 & 22 & 13 & $29.33 \pm 12.11^{\mathbf{b}}$ \\
Tenebrionidae & 15 & 22 & 18 & $18.33 \pm 2.02^{\mathbf{b}}$ \\
Trogiidae & 14 & 11 & 18 & $14.33 \pm 2.03^{\mathbf{b}}$ \\
Scarabeidae & 3 & 0 & 2 & $1.67 \pm 0.88^{\mathbf{b}}$ \\
\hline
\end{tabular}

Total number of beetles in all sites 2648

ANOVA followed by the Newman-Keuls test at the 5\% threshold, $\mathrm{N}=3 ; \mathrm{P}=0.000000 ; \mathrm{ddl}=5 ; \mathrm{F}=111.16$. The numbers followed by the same letter are not significantly different according to the Newman Keuls test at the $5 \%$ threshold.

Table.3 The cadaveric evolution of pigs and order of colonization by necrophagous insects

\begin{tabular}{|c|c|c|c|c|}
\hline $\begin{array}{c}\text { Post } \\
\text { Mortem } \\
\text { Intervals }\end{array}$ & Decomposition phase of the corpse & $\begin{array}{c}\text { Cadaveric } \\
\text { evolution }\end{array}$ & $\begin{array}{c}\text { Order of appearance and } \\
\text { colonization by necrophagous } \\
\text { insects }\end{array}$ & $\begin{array}{c}\text { Weather } \\
\text { conditions }\end{array}$ \\
\hline & & Average \\
daily \\
$\mathrm{d}_{0}$
\end{tabular}




\begin{tabular}{|c|c|c|c|c|}
\hline $\begin{array}{c}\mathrm{d}_{1} \\
(18.03 .2016)\end{array}$ & (1) & $\begin{array}{l}\text { Bloating and } \\
\text { the beginning } \\
\text { of active } \\
\text { decomposition }\end{array}$ & $\begin{array}{c}\text { Calliphoridae } \\
\text { SarcophagidaeMuscidae(Presence } \\
\text { of adults and eggs laid [selected } \\
\text { from the image]). }\end{array}$ & $\begin{array}{c}\text { Average } \\
\text { daily } \\
\text { temperature } \\
28.4^{\circ} \text { CDaily } \\
\text { Relative } \\
\text { Humidity } \\
86 \% \\
\text { Daily rainfall } \\
37.1 \mathrm{~mm}\end{array}$ \\
\hline $\begin{array}{c}\mathrm{d}_{3} \\
(20.03 .2016)\end{array}$ & of & $\begin{array}{c}\text { Active } \\
\text { decomposition }\end{array}$ & $\begin{array}{c}\text { Calliphoridae } \\
\text { Sarcophagidae } \\
\text { Muscidae } \\
\text { (Massive presence of L1-L2 } \\
\text { larvae on all parts of the corpse / } \\
\text { Reduced presence of adult } \\
\text { Diptera) } \\
\text { Hyménoptères }\end{array}$ & $\begin{array}{c}\text { Average } \\
\text { daily } \\
\text { temperature } \\
29.0^{\circ} \mathrm{C} \\
\text { DailyRelative } \\
\text { Humidity } \\
83 \% \\
\text { Daily rainfall } \\
1 \mathrm{~mm}\end{array}$ \\
\hline $\begin{array}{c}\mathrm{d}_{7} \\
(24.03 .2016)\end{array}$ & & $\begin{array}{c}\text { Active } \\
\text { decomposition }\end{array}$ & $\begin{array}{c}\text { Calliphoridae } \\
\text { Sarcophagidae } \\
\text { Muscidae (Massive presence of } \\
\text { larvae L2-L3 at all parts of the } \\
\text { corpse / early pupation / Reduced } \\
\text { presence of adult Diptera) } \\
\text { Hyménoptères }\end{array}$ & $\begin{array}{c}\text { Average } \\
\text { weekly } \\
\text { temperature } \\
28.7^{\circ} \mathrm{C} \\
\text { Average } \\
\text { weekly } \\
\text { relative } \\
\text { Humidity } \\
82.4 \% \\
\text { Average } \\
\text { weekly } \\
\text { Rainfall7.2 } \\
\text { mm }\end{array}$ \\
\hline $\begin{array}{c}\mathrm{d}_{14} \\
(31.03 .2016)\end{array}$ & $\bar{z}$ & $\begin{array}{c}\text { Active } \\
\text { decomposition }\end{array}$ & $\begin{array}{c}\text { Massive presence of nymphs and } \\
\text { near absence of larvae of Diptera } \\
\text { arising. } \\
\text { Appearance of Adult Piophilidae } \\
\text { Diptera. } \\
\text { Appearance of Adult Coleoptera } \\
\text { Cleridae. }\end{array}$ & $\begin{array}{c}\text { Average } \\
\text { weekly } \\
\text { temperature } \\
29.1^{\circ} \\
\text { CAverage } \\
\text { weekly } \\
\text { relative } \\
\text { Humidity } \\
83.6 \% \\
\text { Average } \\
\text { weekly } \\
\text { Rainfall } 17.8 \\
\text { mm }\end{array}$ \\
\hline $\begin{array}{c}\mathrm{d}_{28} \\
(14.04 .2016)\end{array}$ & Livin & $\begin{array}{c}\text { Advanced } \\
\text { decomposition }\end{array}$ & $\begin{array}{c}\text { Large numbers of larvae and } \\
\text { adults of Piophilidae (Piophila } \\
\text { spp.). } \\
\text { Massive presence of adult } \\
\text { Cleridae (Korynetes spp.). } \\
\text { Quasi absence of larvae and } \\
\text { adults of Calliphoridea- } \\
\text { Sarcophagidae-Muscidae. }\end{array}$ & $\begin{array}{c}\text { Average } \\
\text { weekly } \\
\text { temperature } \\
29.0^{\circ} \\
\text { CAverage } \\
\text { weekly } \\
\text { relative } \\
\text { Humidity } \\
81.9 \% \\
\text { Average } \\
\text { weekly } \\
\text { Rainfall } 0.4 \\
\text { mm }\end{array}$ \\
\hline
\end{tabular}




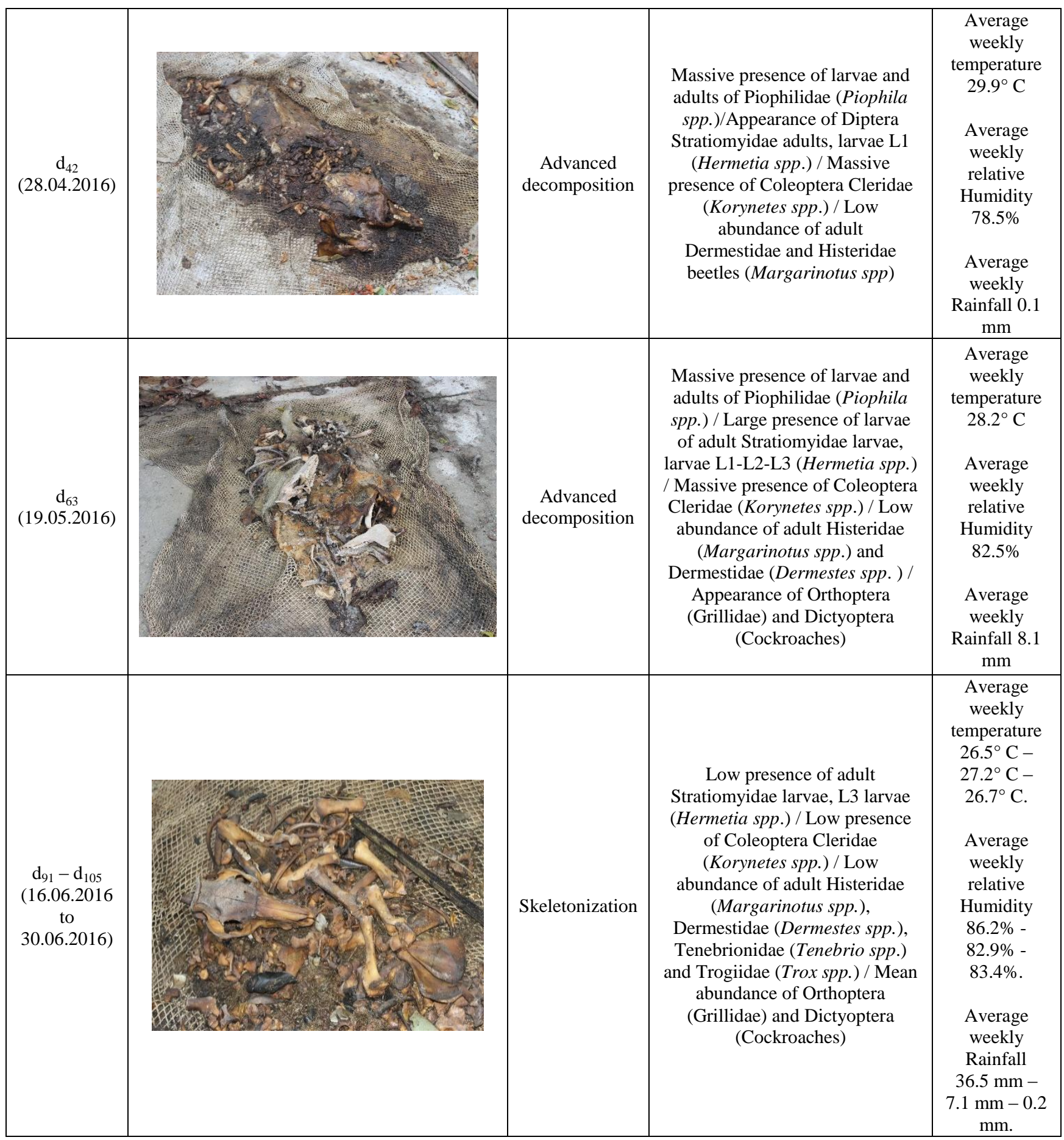


Fig.1 Location of experimental sites (CNRA, Abidjan National Zoo and CNF) in the city of Abidjan (Source: www.mondecarte.com)

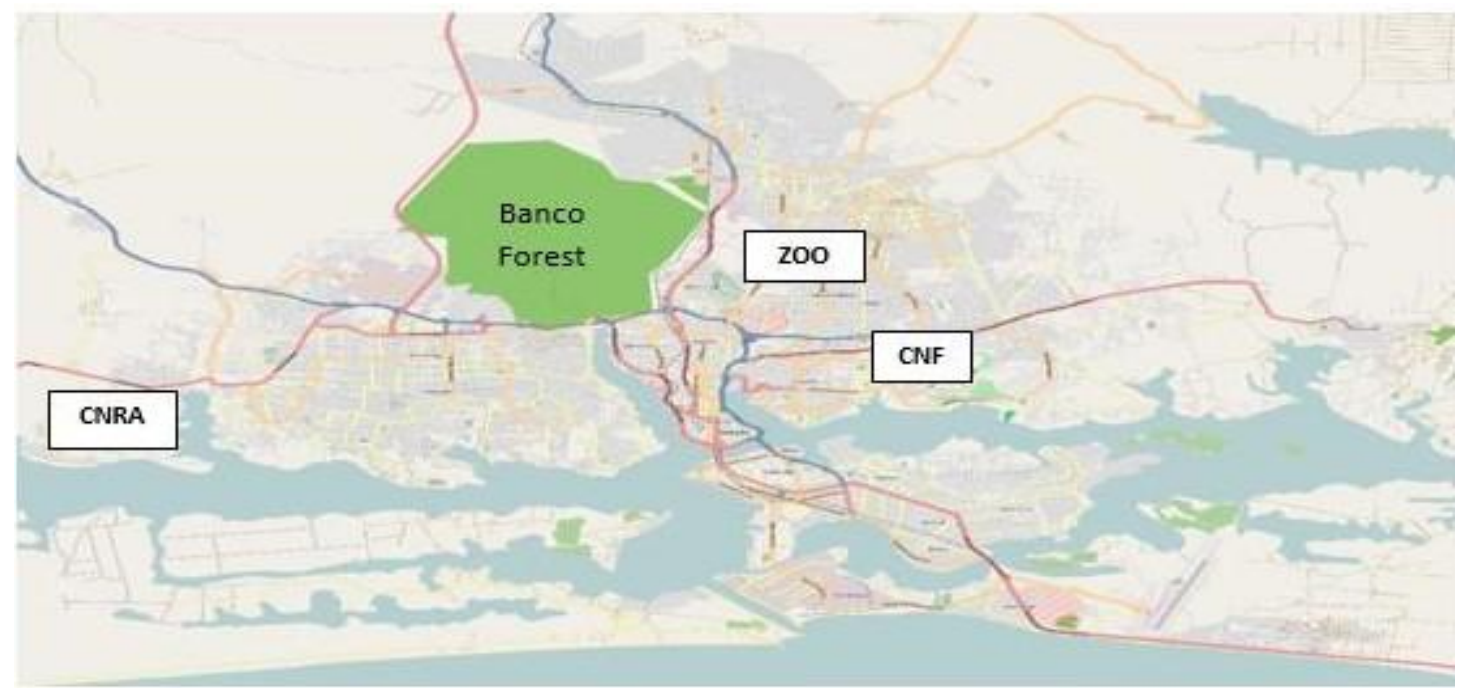

Fig.2 A - Diptera trapping device, B - Device for attracting all insects associated with cadavers, C - Picking eggs from Diptera on the corpse, D - Larval breeding and emergence of Diptera adults in the laboratory
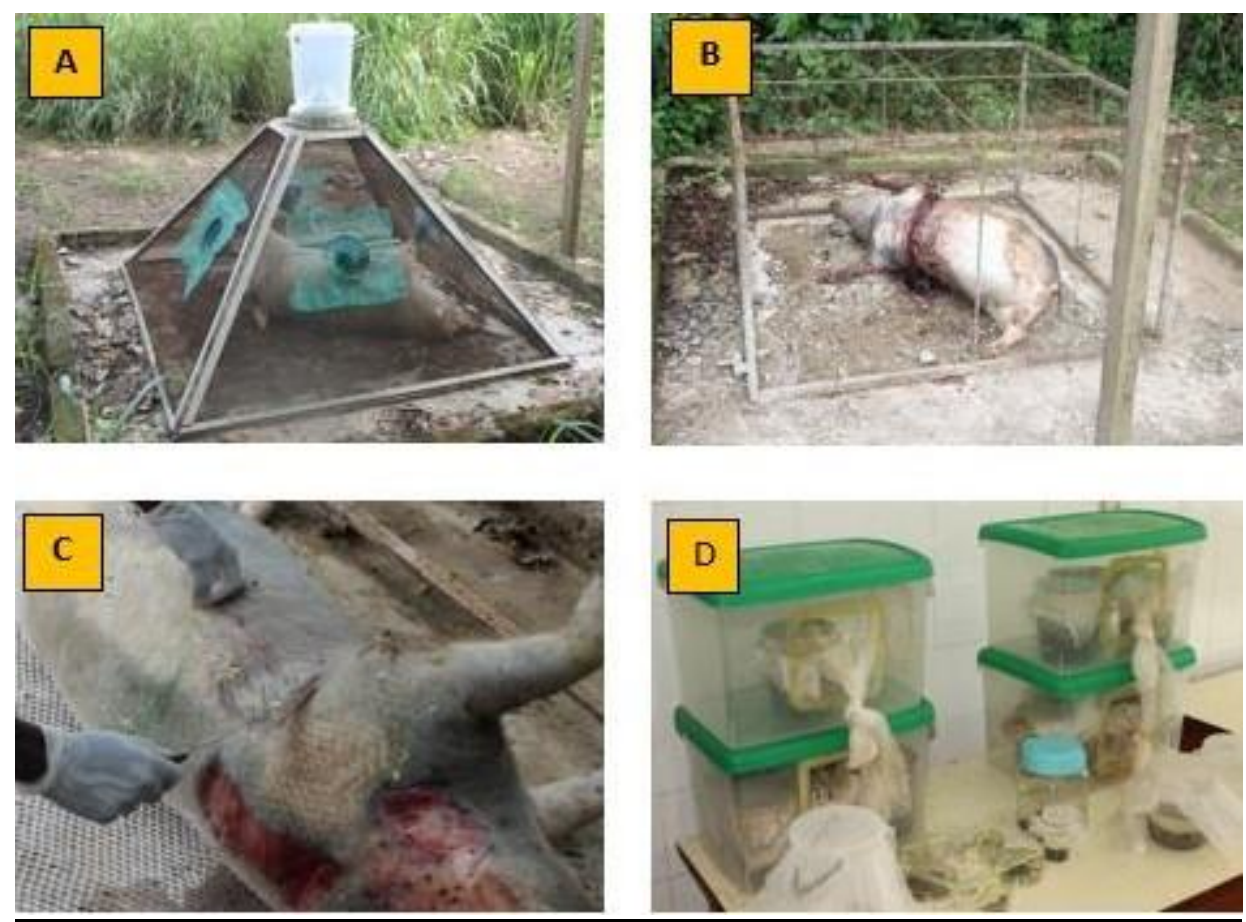
Fig.3 Proportions of different species component all necrophagous Diptera trapped on the three experimental sites

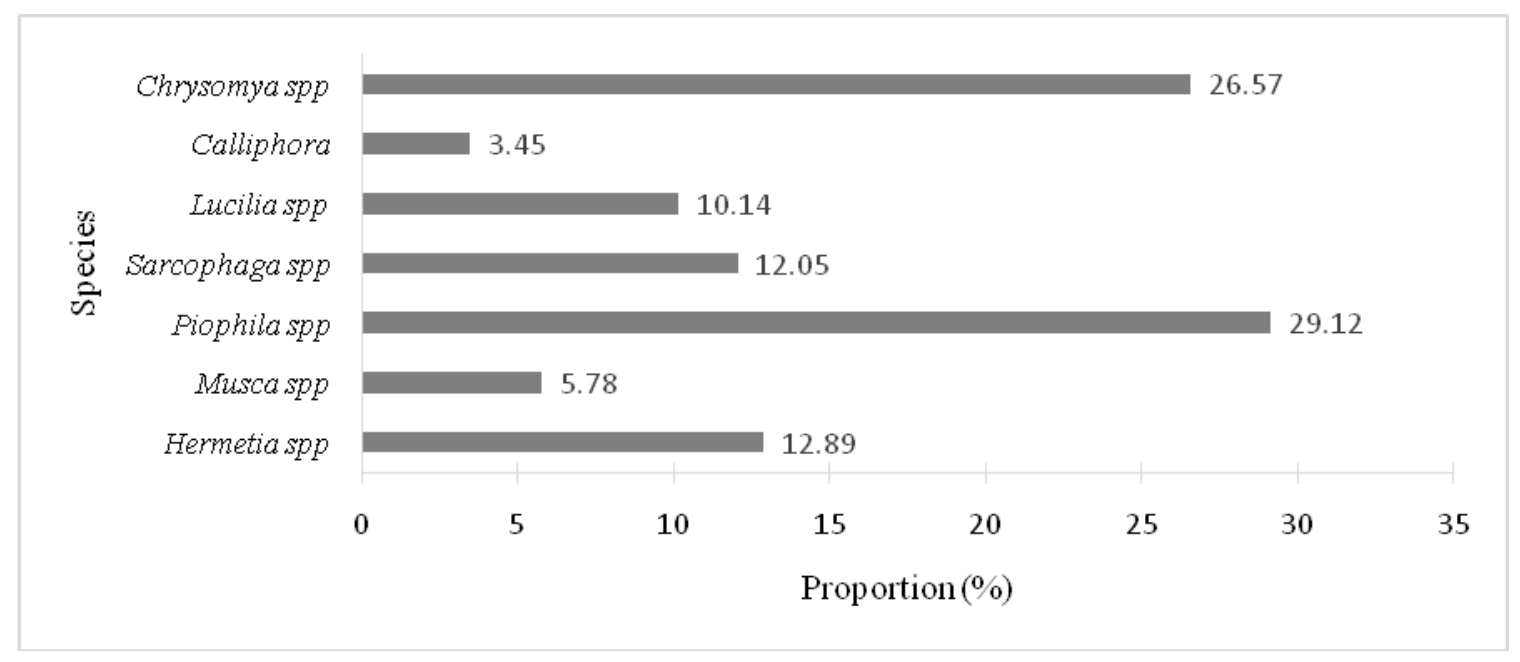

Fig.4 Order of appearance and succession of different groups of necrophagous insects in the process of colonization of a pork corpus exposed to the open air in the southern forest zone of Côte d'Ivoire

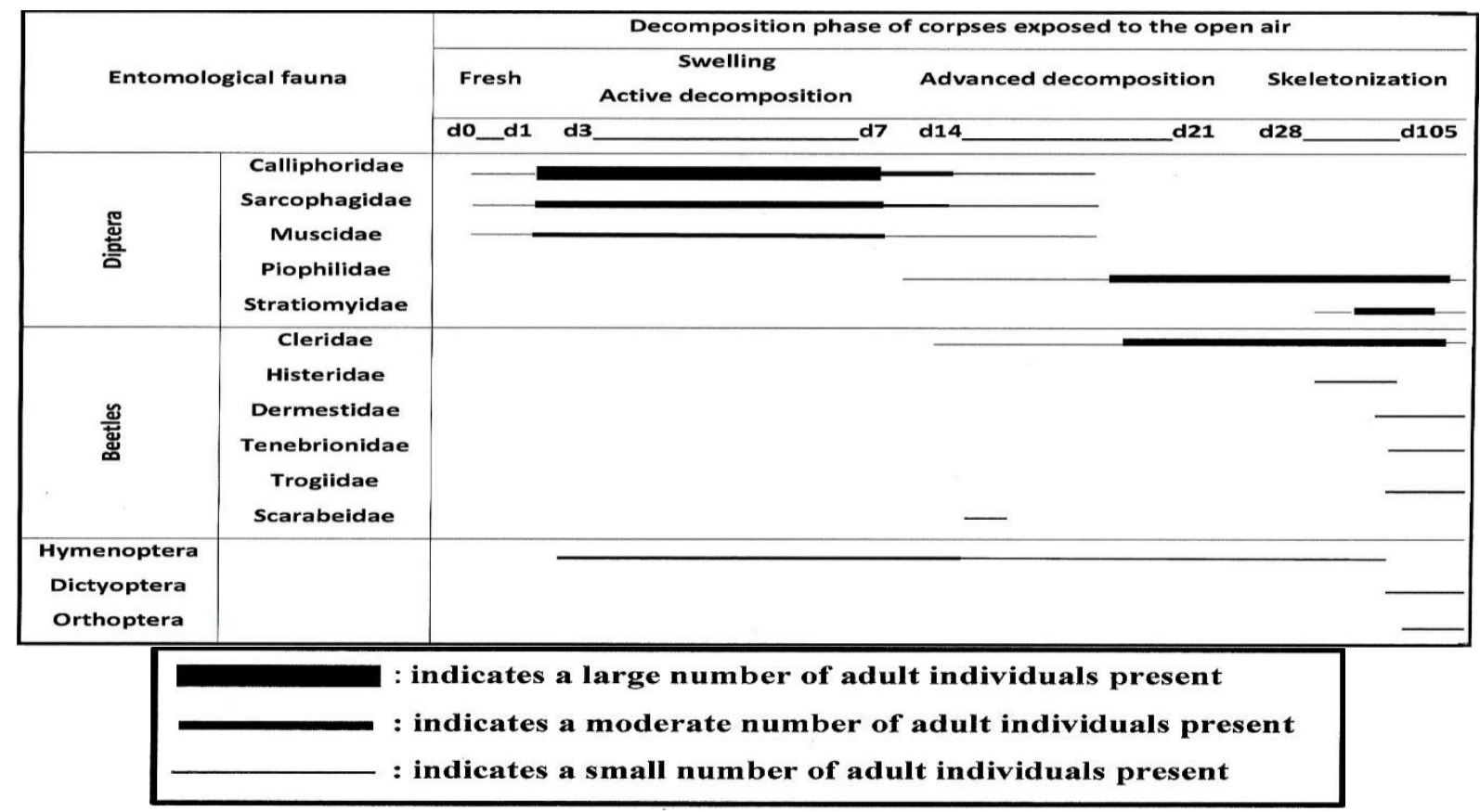

It emerges from this work that a corpse exposed to the open air, in the southern forest zone of Côte d'Ivoire, is very quickly colonized by necrophagous insects. These appear gradually, in quality and quantity, throughout the process of decomposition of the corpse. This progressive colonization, both qualitatively and quantitatively, exhibited the same characteristics on the three experimental sites. As part of an entomological assessment, the results obtained during the work carried out in the Guinean zone of Côte d'Ivoire already give an overview of the different groups of necrophagous insects that an expert is likely to encounter on an exposed corpse outdoors.

\section{Acknowledgment}

The authors are grateful to the Scientific Research Support Program (PASRES), which financed this work, which is part of the PASRES Thesis Project No. 130, the Swiss Center for Scientific Research in Côte d'Ivoire (SCSR/CSRS), Administrative Officers of the CNRA, the ZOO National of Abidjan and the CNF. The authors 
are particularly grateful to Dr. Damien CHARABIDZE [ForensicEntomologist at the Institute of Forensic Medicine of Lilles (France) and at the University of Lille II] for his wise advices.

\section{References}

Adou, H. K., 2014. Etude de la faune cadavérique dans l'estimation du délai post mortem, décomposition de deux primates en sol ferralitique à Abidjan. Mémoire. Edition universitaire européenne. 108 p.

Amendt, J., Krettek, R., Zehner, R. 2004. Forensic entomology. Naturwissenschaften, 91, 51-65.

Anderson, G.S. and VanLaerhoven, S.L., 1996. Initial studies on insect succession on carrion in Southwestern British Columbia. Journal of Forensic Science. 41: 617-625.

Byrd, J. H., Castner, J. L., 2001. Insects of Forensic Importance. Forensic Entomology. The Utility of Arthropods in Legal Investigations. Boca Raton, London, New York, Washington, D.C., CRC Press. 43-79.

Campobasso, C. P., Di Vella, G., Introna, F. 2001. Factors affecting decomposition and Diptera colonization. Forensic Science International, 120, 18-27.

Carmo R.F.R. and Vasconcelos S. D., 2016. Assemblage of necrophagous Diptera in Atlantic insularenvironments and response to different levels of human presence. Neotrop Entomol. 45: 471-481.

Catts, E.P., Goff, M.L., 1992. Forensic entomology in Criminal Investigations. Annual review of entomology. 37:253-272.

Claudio, J. B. C., Cátia, A. M-P., 2008. Key to the adults of the most common forensic species of Diptera in South America.Revista Brasileira de Entomologia, 52(3): 390-406.

Couri, S. M., 2007. A key to the Afrotropical genera of Muscidae (Diptera). Revista Brasileira de Zoologia 24, 175-184.

Dao H., Aboua, L. R. N., Koffi A. F., Kpama-Yapo, C. E. Y., 2017. Biological parameters of sarcophaga carnaria 1. (Diptera: Sarcophagidae) necrophagous fly breeding on two pig substrates (sus scrofa domesticus 1.) at the national floristic center, Abidjan, Côte d'Ivoire. International Journal of Research and Development Organisation, 3(1): 116.

Dekeirsschieter, J., 2007. Etude des odeurs émises par des carcasses de porc (Sus domesticus L.) en décomposition et suivi de la colonisation postmortem par les insectes nécrophages. Mémoire de fin d'études. Faculté universitaire des sciences agronomiques de Gembloux. 104pp.

Delvare, G., Alberlenc, H-P., 1989. Les insectes d'Afrique et d'Amérique tropicale: clés pour la reconnaissance des familles. Ouvrage, CIRAD. 82pp.

Feugang, Y. F. D., Bilong, C. F., Chérix, D., DjiétoLordon, C., 2012. Biodiversity study of arthropods collected on rat carrion in Yaounde, Cameroon: first study on forensic entomology in Central Africa, Int. J. Biosci. 2(1): 1-8.

Gillon, Y., 1990. Extinction et conservation des espèces d'insectes. Cahiers d'Outre-mer 43(172): 375-391.

Goff, M. L. 2009. Early post-mortem changes and stages of decomposition in exposed cadavers. Experimental and Applied Acarology, 49, 2136.Irish, S., Lindsay, T., Wyatt, N., 2014. Key to adults of Afrotropical species of the genus Chrysomia Robineau-Desvoidy (Diptera: Calliphoridae). African Entomology, 22(2): 297306.

Irish, S., Lindsay, T., Wyatt, N., 2014. Key to adults of Afrotropical species of the genus Chrysomia Robineau-Desvoidy (Diptera: Calliphoridae). African Entomology, 22(2): 297-306.

Lee H. 1989. Recovery of forensically important entomological specimens from human cadavers in Malaysia an update. Malays. J. Pathol. 11: 33.

Lee H., M. Krishnasamy, A. Abdullah and J. Jeffery. 2004. Review of forensically important entomological specimens in the period of 19722002. Trop. Biomed. 21: 69.

Leclercq, M. 1978. Entomologie et Médecine légale. Datation de la mort. Masson (Paris), Collection de médecine légale et de toxicologie médicale: $100 \mathrm{p}$.

Leclercq, M., 1996. A propos de l'entomofaune d'un cadavre de sanglier. Bull. Annls Soc. R. belge Ent. 132 (1996): 417-422.

Lord W. D., M. L. Goff, T. R. Adkins, N. H. Haskell, 1994.The black soldier fly Hermetia illucens (Diptera: Stratiomyidae) as a potential measure of human postmortem interval: observations and case histories, J. ForensicSci. 215-222.

Mégnin, J. P., 1894. La faune des cadavres: application de l'entomologie à la médecine légale. GauthierVillars et fils, 210pp.

Prins, A. J., 1982. Morphological and biological notes on six South African Blow-flies (Diptera, Calliphoridae) and their immature stages. Ann.S.Afr.Mus. 90, 201-217.

Regina, M. C., 2002. Identification key to the common forensically important adult flies (Diptera) of 
Northen

http://www.nku.edu./biosci/courses degree /forensic fly key/homepage.htm.

Rodriguez,W.C., Bass, W.M., 1983. Insect activity and its relationship to decay rates of human cadavers in East Tennessee. Journal of Forensic Sciences. 28(2): 423-432.

Smith, K.G.V., 1986. A Manual of Forensic Entomology. Ithaca, Comstock Publishing Associates, Cornell Univ Pr. 205p.

Szpila, K., 2009. Key for identification of European and Mediterranean blowflies (Diptera, Calliphoridae) of forensic importance Adult flies. http://www.eafe.org/. 18pp.

Turchetto M., 2000. Implicazioni entomologica-forensi dell'introduzione in Italia della mosca neotropicale Hermetia illuscens L. (Diptera: Stratiomyidae), Rivista taliana di Medicina legale. (22): 12791290.

Upton, M. S., 1991. Methods for collecting, preserving, and studying insects and allied forms. The Australian entomological Society, Miscellaneous Publ. No. 3, fourth edition, Brisbane: $v+86 \mathrm{p}$.
Watson E. J. and Carlton C. E., 2005. Insect Succession and Decomposition of Wildlife Carcasses During Fall and Winter in Louisiana. Journal of Medical Entomology, 42(2):193-203. DOI: http://dx.doi.org/10.1603/00222585(2005)042[0193:ISADOW]2.0.CO;2

Whitworth, T., 2010. Keys to the genera and species of blow flies (Diptera: Calliphoridae) of the West Indies and description of a new species of Lucilia Robineau-Desvoidy. Zootaxa, 2663: 1-35.

Wyss C., 2000. Enquête entomologique 83-insp, détermination du délai post-mortem (IPM). Annexe 2

Wyss. C., Cherix, D., 2006.Traité d'entomologie forensique. Presses Polytechniques et Universitaires Romandes, Lausanne, 317p.

Yapo, C. E. Y., Aboua, L. R. N., Koffi A. F., Dao, H., 2017. Some biological parameters of Lucilia sericata M., (Diptera: Calliphoridae) necrophagous insect breeding on pig (Sus scrofa domesticus L.) and beef's (Bos indicus) liver at the National Center of Floristic, guinean zone of Côte d'Ivoire. Int.J.Curr.Res.Aca.Rev., 5(1): 68-76.

\section{How to cite this article:}

Koffi Alexandre Franklin, Aboua Louis Roi Nondenot, Dao Hassane, Djojo Mathurin, D.E. Koffi-Tebele Joëlle, E.Y. Kpama-Yapo Carine. 2017. Process of Colonization by Necrophagous Insects, of a Pig Corpse (Sus scrofa domesticus L.) Exposed at Open Air, in the Southern Forest Zone of Côte d'ivoire. Int.J.Curr.Res.Aca.Rev. 5(7), 103-114. doi: https://doi.org/10.20546/ijcrar.2017.507.014 